Сурков О. О., канд. військ. наук

$(0000-0002-8189-0484)$

Сафронов О. В. , д-р техн. наук, професор

$(0000-0001-7420-0062)$

Романюк А. М.

(0000-0002-4268-0601)

Центр воєнно-стратегічних досліджень Національного університету оборони України імені Івана Черняховського, Київ

\title{
Методичний підхід до визначення варіанта стратегії та критеріїв досягнення спільних оборонних спроможностей Збройних Сил та інших складових сил оборони
}

Резюме. Розроблено методичний підхід до визначення варіанта стратегії та критеріїв досягнення спільних оборонних спроможностей Збройних Сил та інших складових сил оборони. Запропоновано ієрархічну структуру варіанта стратегії, критерії оцінювання іï результативності обраної стратегії та основні етапи.

Ключові слова: методичний підхід; стратегія; Збройні Сили; сили оборони; критерії оцінювання; оборонні спроможності; оборонний огляд.

Постановка проблеми. Результати оборонного огляду $\epsilon$ основною інформаційною платформою, на базі якої визначається стратегія розбудови сил оборони, критеріїв досягнення їх спільних оборонних спроможностей, стратегічні (оперативні) цілі їх розвитку, а також розробляються стратегічні документи щодо розвитку сил оборони.

Отже, розроблення та удосконалення наукових методів, підходів і методик, які підвищують об'єктивність результатів проведення оборонного огляду, а також дають змогу визначити раціональну стратегію та критерії досягнення спільних оборонних спроможностей Збройних Сил та інших складових сил оборони залишається актуальною науковою і прикладною задачею.

Аналіз останніх досліджень i публікацій. У статті [1] розкрита сутність стратегічного планування за допомогою аналізу співвідношення між термінами i поняттями, такими як стратегія і стратегічний план, менеджмент i планування, довгострокове і стратегічне планування.

Підкреслено, що спочатку визначається бажаний стан організації, якого хочуть досягнути в майбутньому, а потім, за допомогою системного аналізу i формалізованої процедури, визначають шляхи, засоби та ресурси, необхідні для досягнення цього стану [1].

Зазначено також, що стратегія - це модель поведінки, спрямованої на досягнення поставлених цілей, набір правил для пошуку і використання можливостей, а стратегічний план - послідовність певних кроків та дій, інтегрованих у просторі та часі, що приводять до зміни поточного стану на бажане.

У праці [2] пріоритети національних інтересів держави запропоновано класифікувати за трьома рівнями важливості (життєво важливі, важливі, периферійні) та чотирма категоріями:

захист Батьківщини; економічне процвітання;

гармонійний розвиток українського суспільства;

створення сприятливих умов для ефективної участі країни у світовому поділі праці.

у навчальному посібнику [3] розроблено теоретико-методологічні засади системних досліджень проблем забезпечення національної безпеки, зокрема розроблено метод обгрунтування варіантів стратегічних рішень у сфері забезпечення національної безпеки, який сприяє підвищенню об'єктивності, гнучкості, адаптивності та ефективності формування державної політики у сфері державного управління забезпеченням національної безпеки держави.

Формування та вибір варіантів стратегічних рішень запропоновано здійснювати через застосування процедур генерування та фільтрації альтернатив, шляхом ітераційного пошуку (рекурсивного способу) та системи критеріїв відбору альтернативних стратегічних рішень [3].

Зазначено, що цей метод після уточнення головної мети стратегічного планування для відповідної сфери, критеріїв (критерію) та показників iї досягнення може 
бути поширений на інші сфери життєдіяльності держави і суспільства.

$$
\text { У статті [4] запропоновано }
$$

концептуальний підхід до визначення

пріоритетних напрямів розвитку

спроможностей ЗС України та інших

складових сил оборони на довго- та

середньострокову перспективу із

використанням рекурсивного способу.

Сутність концептуального підходу полягає у застосуванні рекурсії до визначених етапів, упорядкованих за ступенем деталізації та взаємозв'язком необхідної вхідної та вихідної інформації для розрахунків i підтримки прийняття раціональних стратегічних рішень [4].

Зазначено [4], що рекурсивний спосіб також використовують у різних спеціальних галузях знань, зокрема у математиці та програмуванні для оптимізації складного обчислювального процесу, скорочення алгоритму, врахування нескінченно великої кількості даних під час планування та побудови механізму забезпечення прийняття рішень.

У навчальному посібнику [5] викладено основи теорії прийняття рішень. Подано базові поняття моделі, методів і алгоритмів, які визначають процеси прийняття рішень i можуть бути використані під час обгрунтування методичних підходів до визначення варіантів розвитку Збройних Сил та інших складових сил оборони.

У праці [6] зазначено, що визначення стратегічних цілей розпочинається 3 уточнення кінцевої мети (місіі) організації. Вони мають демонструвати, що конкретно потрібно досягнути у межах реалізації місії, відповідати низці вимог, бути сформульованими у якісному виразі. До того ж, підлягають уточненню шляхи досягнення стратегічних цілей.

На думку автора [7], кожна організація має свою систему цілей, що визначається внутрішньою структурою, сферою діяльності, становищем у зовнішньому середовищі тощо. Запропоновані вимоги до формування стратегічних цілей можуть бути використані під час обгрунтування варіантів стратегії та критеріїв досягнення спільних оборонних спроможностей Збройних Сил та інших складових сил оборони.

Серед загальних стратегій, які мають місце впродовж “життєвого циклу” організації, розрізняють [8]:

стратегії зростання;

стратегії стабілізації; стратегії скорочення;

стратегію реструктуризації.

Отже, проведений аналіз свідчить про необхідність розроблення методичних підходів до визначення варіантів стратегії та критеріїв досягнення спільних оборонних спроможностей Збройних Сил та інших складових сил оборони.

Метою статті $\epsilon$ розроблення методичного підходу до визначення варіанта стратегії та критеріїв досягнення спільних оборонних спроможностей Збройних Сил та інших складових сил оборони для науковометодичного забезпечення виконання Міжвідомчою робочою групою завдання основного етапу оборонного огляду щодо визначення стратегії розбудови сил оборони, критеріїв досягнення ї необхідних спроможностей, a також стратегічних (оперативних) цілей їх розвитку.

Викладення основного матеріалу. До основних чинників, які впливають на вибір варіантів стратегії та критеріїв досягнення спільних оборонних спроможностей сил оборони належать [9]:

безпекове середовище (глобальні, регіональні та національні аспекти) у контексті світових тенденцій зміни воєнної політики та воєнної безпеки;

цілі, пріоритети і завдання, які визначені вищим воєнно-політичним керівництвом держави на довгострокову перспективу;

існуючий стан і готовність сил оборони до виконання завдань за функціональним призначенням, їх кадрового, фінансового, матеріально-технічного та інших видів забезпечення;

розвиток форм і способів застосування військ (сил), а також ефективність їх застосування у воєнних конфліктах;

соціально-політичні, економічні та інші умови реалізації державної політики у воєнній cферi, сферах оборони i військового будівництва, а також воєнно-політичні та воєнно-стратегічні обмеження.

Також на вибір варіантів стратегії та критеріїв досягнення спільних оборонних спроможностей сил оборони впливають результати виконання завдань основного етапу оборонного огляду [10]:

оцінка стану та перспектив розвитку безпекового середовища; огляд спроможностей за їx функціональними групами; планування сил; планування ресурсів; 
формування перспективної моделі Збройних Сил та інших складових сил оборони та їх структури.

Стратегія розвитку ЗС України та інших складових сил оборони (далі - ЗС України та ICCO) має бути спрямована на задоволення їх потреб у спроможностях, необхідних для вирішення повного спектру завдань за визначеними сценаріями та бути результативною.

Під результативністю пропонується розуміти рівень відповідності досягнутих результатів поставленій меті, які дають позитивний ефект від впровадження під час раціонального використання фінансових ресурсів.

Як було зазначено, автори праці [2] пріоритети національних інтересів держави запропонували класифікувати за чотирма категоріями. У статті визначення варіанта стратегії розвитку ЗС України та ICCO пропонується здійснювати за трьома категоріями, які по суті $\epsilon$ критеріями оцінювання результативності варіанта стратегії.

Вибір критеріїв оцінювання результативності варіанта стратегії здійснено 3 урахуванням пріоритетів державної політики у воєнній сфері, сферах оборони і військового будівництва, які запропоновані у праці [12].

Оцінювання результативності варіанта стратегії розвитку ЗС України та ICCO (згортання обраних критеріїв) можна представити у вигляді:

$$
K_{\text {РОС }}=F\left(K_{\text {Од }}(n, p) ; K_{\text {НнС }}(n, p) ; \quad K_{\text {чн }}(n, p)\right) \Rightarrow \max \text {, }
$$

де $K_{\text {рос }}-$ узагальнений критерій результативності варіанта стратегії, який характеризує результативність стратегії розвитку ЗС України та ICCO;

$K_{\text {од }}$-критерій обороноздатності держави, який характеризує готовність ЗС України та ICCO забезпечити захист суверенітету, територіальну цілісність і недоторканність державного кордону України;

$K_{\text {НнС }}$ - критерій набуття необхідних спроможностей, який характеризує здатність 3C України та ICCO набути необхідні спроможності;

$K_{\text {чн }}-$ критерій членства в НАТО, який характеризує здатність ЗС України досягти критеріїв членства в НАТО та спроможності

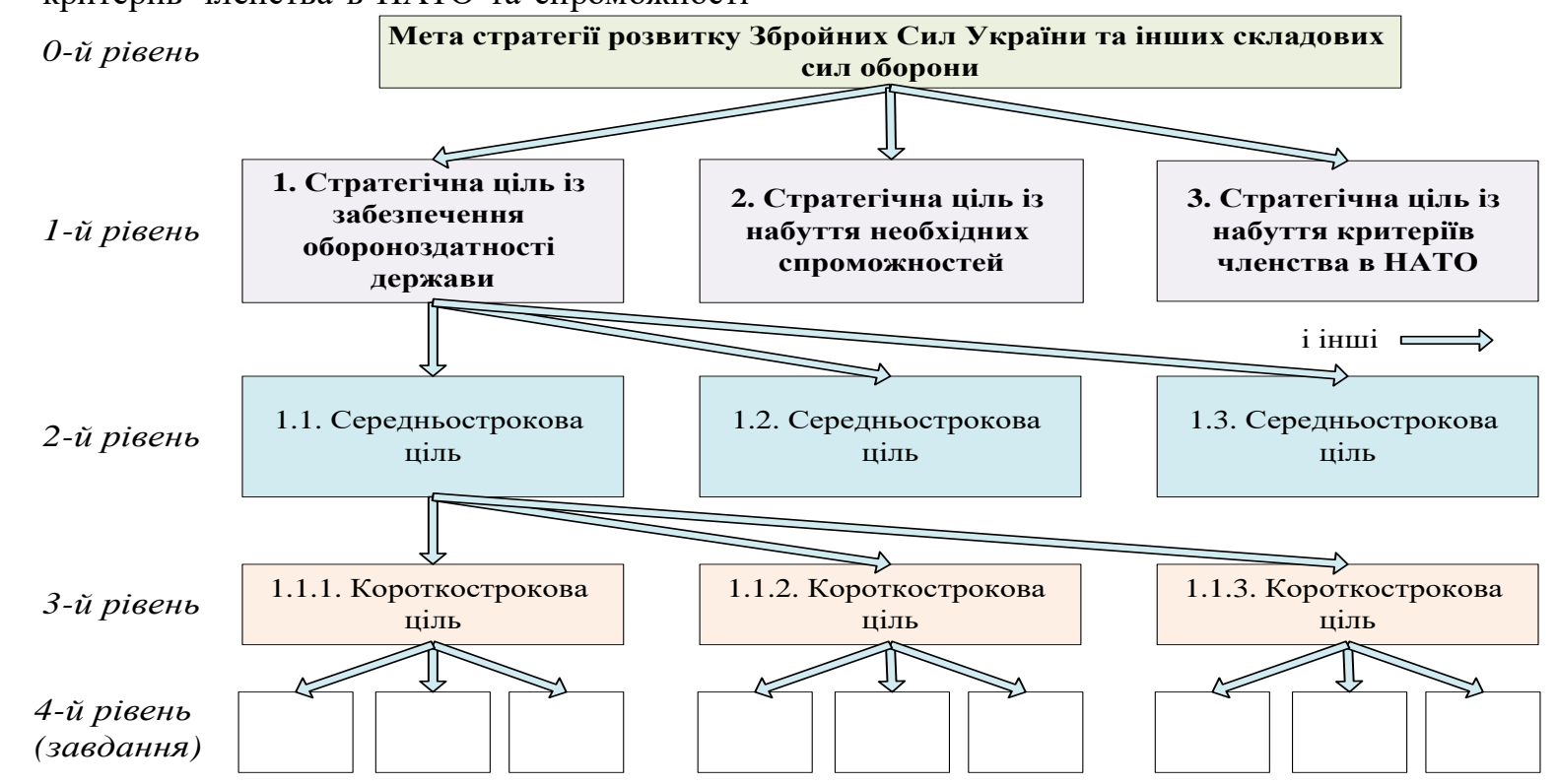

Рис. 1. Ієрархічна структура варіанта стратегії розвитку Збройних Сил України та інших складових сил оборони робити внески військового та невійськового характеру в колективну оборону та у виконання нових завдань, які постають перед Україною;

$n$ - сукупність часткових та узагальнених показників;

$p$ - сукупність параметрів часткових показників, які забезпечують найбільше значення узагальненого критерію результативності серед всіх можливих значень.

Для визначення стратегії та критеріїв досягнення спільних оборонних спроможностей сил оборони пропонується скористатися ієрархічною структурою варіанта стратегії розвитку 3С України та ICCO, яка наведена на рис. 1. 
Стратегія розвитку ЗС України та ICCO, на нашу думку, має включати довгострокову мету та визначені стратегічні цілі (1-ü рівень) на період понад п'ять років (див. рис. 1). Кожна стратегічна ціль має включати середньострокові цілі (2-ц̌ рівень) на період до п'яти років та короткострокові цілі (3-й рівень) із терміном до трьох років, які характеризуватимуть проміжні результати (результативні показники) оборонної реформи, а також визначені пріоритети та стратегічні завдання силам оборони.

На підставі визначених стратегічних, середньострокових та короткострокових цілей необхідно також буде визначити завдання (4-ц̌ рівень), які необхідно виконати для досягнення визначених цілей. Визначені завдання та заходи складатимуть основу середньострокових державних програм із розвитку ЗС України та ICCO і короткострокових планів утримання та розвитку. До того ж, кількість цілей на кожному рівні (1-3-ц̌ piвнi) рекомендується обирати від 3 до 7.

Щоб вибрати найкращу стратегію із можливих варіантів, необхідно також визначити значення узагальненого

критерію результативності варіанта стратегії розвитку сил оборони, а також критеріїв обороноздатності держави, набуття необхідних спроможностей та членства в НАТО.

Результативність реалізації варіанта стратегії прийнято оцінювати за критерієм Гурвіца (критерій песимізму-оптимізму), який відображає найбільш зважену позицію між очікуванням на краще та очікуваннями на гірше і характеризується коефіцієнтом оптимізму [11]. Значення цього коефіцієнта автор праці [11] пропонує обирати в межах 0,3-0,7.

У нашому методичному підході пропонується:

для визначення песимістичного варіанта результативності стратегії, прийняти значення цього коефіцієнта рівним 0,3 ;

для визначення найбільш вірогідного варіанта - 0,5;

для визначення оптимістичного варіанта $-0,7$.

Для аналізу очікуваних та отриманих результатів реалізації варіанта стратегії, пропонується також прийняти однакові значення для критеріїв результативності, які наведено у табл. 1.

Таблиця 1

Значення критеріїв оцінювання результативності обраної стратегії розвитку сил оборони

\begin{tabular}{|c|c|c|}
\hline \multicolumn{2}{|c|}{ Значення критеріїв $K_{\text {РОС }}, K_{\text {Од }}, K_{\mathrm{HHC}}, K_{\text {чн }}$} & Коефіціснт оптимізму \\
\hline Задовільний (песимістичний варіант) & & 0,3 \\
\hline Середній (найбільш бах & & 0,5 \\
\hline Високий (оптимістичний варіант) & & 0,7 \\
\hline $\begin{array}{l}\text { Стратегія розвитку сил } \\
\text { повинна оборони } \\
\text { (коефіцієнт оптимізму } 0,3 \text { і більше). Вибір } \\
\text { стратегічних цілей та пріоритетних напрямів } \\
\text { розвитку 3С України та ІССО пропонується } \\
\text { здійснювати на основі стратегії протидії } \\
\text { гібридній війні, застосування й розвитку сил } \\
\text { оборони, до того ж необхідно забезпечити } \\
\text { ефективність використання фінансових } \\
\text { ресурсів (визначити найкращий варіант } \\
\text { стратегії). } \\
3 \text { огляду на зазначене, під час } \\
\text { планування завдань та заходів оборонної } \\
\text { реформи пропонується вважати стратегію та } \\
\text { критерії досягнення спільних оборонних } \\
\text { спроможностей сил задовільною, якщо } \\
\text { приріст результативності від виконання }\end{array}$ & $\begin{array}{r}\text { визначен } \\
\text { песиміст } \\
\text { Ст } \\
\text { до визна } \\
\text { досягнен } \\
\text { спромож } \\
\text { складови } \\
\text { Кр } \\
\text { мети стр } \\
\text { та інших } \\
\text { під час } \\
\text { Стратегіі } \\
\text { оборонн } \\
\text { і переосл } \\
\text { що прог } \\
\text { (складов }\end{array}$ & $\begin{array}{l}\text { аходів складе не гірше } \\
\text { (див. табл. 1). } \\
\text { методичного підходу } \\
\text { стратегії та критеріїв } \\
\text { них оборонних } \\
\text { них Сил та інших } \\
\text { наведена на рис. } 2 . \\
\text { хію та взаємозв'язок } \\
\text { озвитку Збройних Сил } \\
\text { оборони (див. рис. 1) } \\
\text { опозицій до проєктів } \\
\text { еки та Стратегічного } \\
\text { країни слід перевіряти } \\
\text { и не буде впевненості, } \\
\text { i базові компоненти } \\
\text { гей та функціональні }\end{array}$ \\
\hline
\end{tabular}


Оцінювання результативності стратегії розвитку Збройних Сил та інших складових сил оборони слід проводити за фактичними результатами виконання попередніх завдань оборонного огляду, згідно із запропонованим методичним підходом до визначення варіанта стратегії та критеріїв досягнення спільних оборонних спроможностей Збройних Сил та інших складових сил оборони (див. рис. 2).

Висновки. На основі проведеного аналізу й узагальнення існуючих методів розв'язання зазначеної проблеми, розроблено методичний підхід до визначення варіанту стратегії та критеріїв досягнення спільних оборонних спроможностей Збройних Сил та інших складових сил оборони.

Запропоновані ієрархічна структура варіанта стратегії розвитку спроможностей Збройних Сил та інших складових сил оборони, критерії оцінювання результативності обраної стратегії та основні етапи ії визначення.

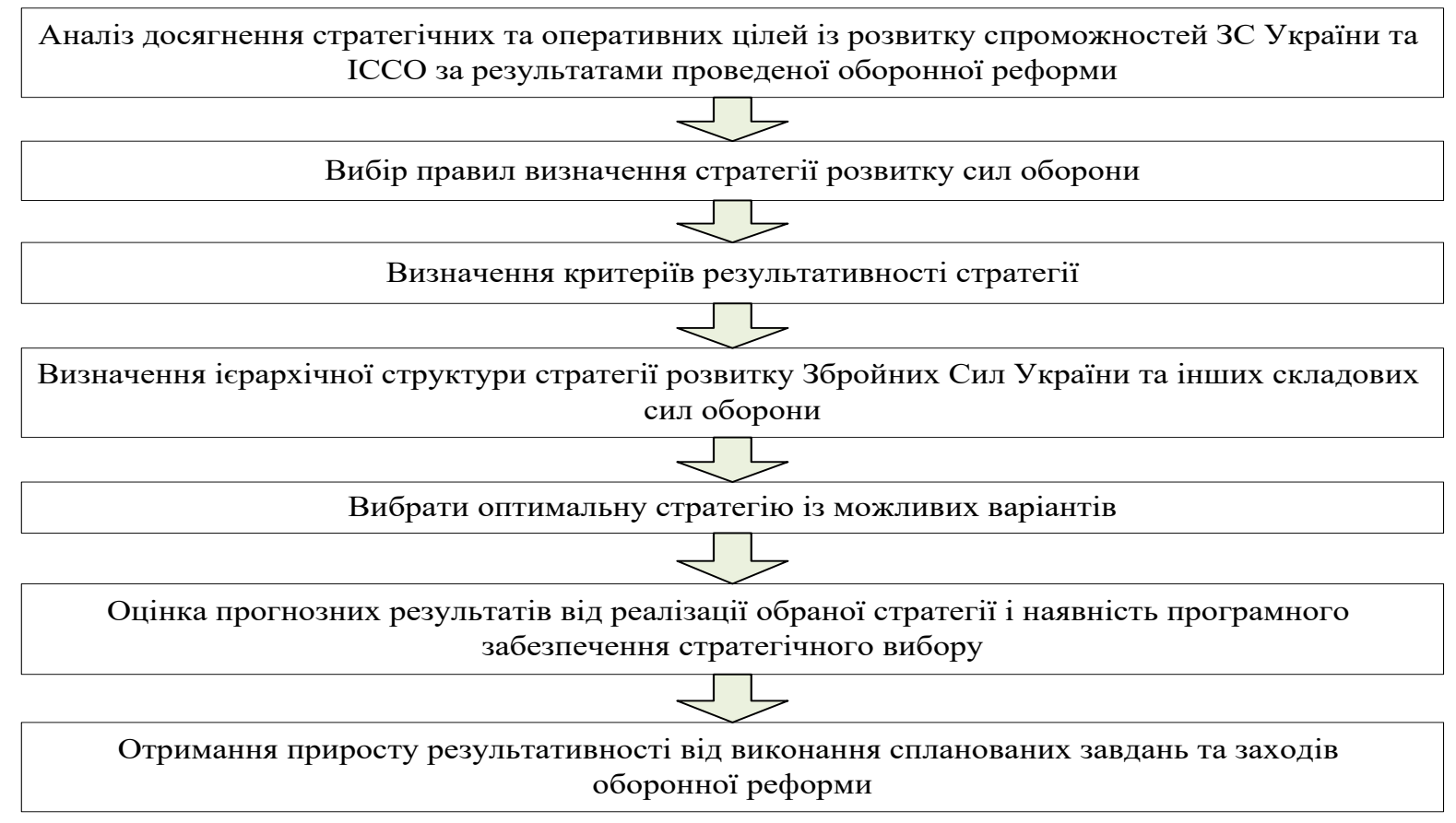

Рис. 2. Структурна схема методичного підходу до визначення варіанта стратегії та критеріїв досягнення спільних оборонних спроможностей Збройних Сил та інших складових сил оборони

Методичний підхід до визначення варіанта стратегії та критеріїв досягнення спільних оборонних спроможностей Збройних Сил та інших складових сил оборони може бути використаний Міжвідомчою робочою групою під час оборонного огляду.

Перспектива подальших досліджень. Подальші дослідження доцільно присвятити удосконаленню методів стратегічного планування розвитку Збройних Сил України та інших складових сил оборони на основі спроможностей.

\section{СПИСОК ВИКОРИСТАНОЇ ЛІТЕРАТУРИ}

1. Свистович М. Б. Сутність та основні поняття стратегічного планування. Державне управління: теорія та практика. 2013. № 2. С. 37-43.

2. Горбулін В. П., Качинський А. Б. Стратегічне планування: вирішення проблем національної безпеки: монографія. Київ : НІСД, 2010. 288 с.

3. Богданович В. Ю., Семенченко А. І., Єжеєв М.Ф. Методи державного управління забезпеченням національної безпеки у іiі визначальних сферах : навч. посіб. Київ : НАДУ, 2008. $136 \mathrm{c}$.

4. Сурков О. О. Концептуальний підхід до вибору пріоритетних напрямів стратегічного планування розвитку спроможностей Збройних Сил України та інших складових сил оборони. Збірник наукових праць Центру воєнно-стратегічних досліджень Національного університету оборони Украӥни імені Івана Черняховського. Київ, 2018. № 2 (63). С. 39-45.

5 Волошин О. Ф., Мащенко С. О. Моделі та методи прийняття рішень: навч. посіб. ; 2-ге вид., перероб. та допов. Київ : Київський університет, 2010. $336 \mathrm{c}$.

6. Азарова Т. В., Абрамов Л. К. Стратегічне планування діяльності НДО : навч.-метод. посіб. Кіровоград : ЦПТІ, 2000. 76 с.

7. Сутність стратегічних цілей та вимоги до їх формування. Проблемь формирования новой экономики XXI века : матеріали III Международної научн.-практ. конф., м. Київ, 2324 грудн. 2010 р. Київ, 2010.

8. Стратегічне управління : навч. посіб. / Т. О. Фролова та ін. 2-ге вид. Київ : Центр учбової літератури, 2016. 440 с. 
9. Про національну безпеку України : Закон України від 21.06.2018 р. № 2469-VIII. URL: http://search. Ligazakon.ua (дата звернення: 31.10.2019).

10. Порядок проведення оборонного огляду Міністерством оборони : затв. постановою КМ України від 31.10.2019 р. № 941. URL: http://
zakon.rada.gov.ua/laws/show/941-2018-\%D0\%BF (дата звернення: 31.10.2019).

11. Волошенко О. О. Методичний підхід до формування стратегії еколого-орієнтованого розвитку підприємства. Ефективна економіка. Дніпро, 2016. № 11.

Стаття надійшла до редакційної колегії 17.12.2019

\section{Methodological approach to determining the strategy and criteria for achieving joint defense capabilities of the Armed Forces and other components of the defense forces}

\section{Annotation}

The article proposes one of the possible methodological approaches to the Interdepartmental Working Group to fulfill the task of the main stage of the defense review to determine the strategy of building defense forces, criteria for achieving their necessary capabilities, as well as strategic (operational) goals of their development.

The main factors influencing the choice of strategy options and criteria for achieving joint defense capabilities of the defense forces are identified, indicators and criteria for evaluating the effectiveness of the strategy option are selected taking into account the priorities of state policy in the military, defense and military construction.

A hierarchical structure of the variant of the development strategy of the Armed Forces of Ukraine and other components of the defense forces is proposed, which contains a long-term goal and defined strategic goals (Level 1) for a period of more than five years. Each strategic goal should contain medium-term goals (Level 2) for a period of up to five years and short-term goals (Level 3) for a period of up to three years, which will characterize the intermediate results (performance indicators) of defense reform, as well as priorities and strategic tasks of the defense forces. At each level, it is suggested to choose from 3 to 7 goals.

On the basis of strategic, medium-term and short-term goals, it is proposed to determine the tasks (Level 4), the implementation of which will be aimed at achieving the goals. The outlined tasks and measures will become the basis of medium-term state programs for the development of the Armed Forces of Ukraine and other components of the defense forces and short-term maintenance and development plans.

It is proposed to evaluate the effectiveness of the variant of the development strategy of the Armed Forces of Ukraine and other components of the defense forces according to the Hurwitz pessimism-optimism criterion. The strategy option will be considered effective provided that the value of the generalized criterion of effectiveness of the defense strategy development strategy, as well as the criteria of state defense capability, acquisition of necessary capabilities and NATO membership will increase by at least $30 \%$ from planned defense reform tasks and measures.

The use of the proposed methodological approach, according to the authors, will improve the quality of development of strategic documents on the development of defense forces.

Keywords: methodical approach; strategy; Armed Forces; defense forces; evaluation criteria; defense capabilities; defense review. 